This is the accepted manuscript of an article published by Taylor \& Francis in International Review of Law, Computers and Technology on 21 March 2013.

The version of record [Romero-Moreno, F. (2013) 'Unblocking the Digital Economy Act 2010, human rights issues in the UK', International Review of Law, Computers \& Technology, 27(1-2): 1845, first published on line March 21, 2013] is available online via doi: http://dx.doi.org/10.1080/13600869.2013.764149 


\section{Unblocking the Digital Economy ACt 2010; Human Rights Issues in THE UK}

\section{INTRODUCTION}

Through an example of a study utilizing the case-law research method, this paper critically assesses whether taking into account the findings of La Rue (the United Nations Rapporteur on Human Rights ${ }^{1}$ ) website blocking could be implemented in a way which is compatible with the European Convention on Human Rights (ECHR). Drawing upon, inter alia, the "Site Blocking" to reduce online copyright infringement paper ${ }^{2}$ (hereinafter Ofcom's review), sections 17 and 18 of the Digital Economy Act 2010 (DEA), namely, the power to make provision about injunctions preventing access to internet locations (hereinafter the site blocking provisions), section 97A of the Copyright Designs and Patents Act (CDPA) as well as some European Court of Human Rights (ECtHR) and Court of Justice of the European Union (CJEU) jurisprudence, this study seeks to answer the question of whether the implementation of any blocking measure might possibly be consistent with the ECHR, in particular, with Article 10.

As the ECtHR held in Times $v U K$ :

"...the Internet plays an important role in enhancing the public's access to news and facilitating the dissemination of information generally. The maintenance of Internet archives is a critical aspect of this role and the Court therefore considers that such archives fall within the ambit of the protection afforded by Article 10., 3

According to the Special Rapporteur, there are several procedural requirements which any limitation to the right to freedom of expression has to follow in order to pass the three-part cumulative test.

- First, it needs to be "prescribed by law" which is clear and accessible to all individuals (principles of predictability and transparency).

- Second, it is required to "protect rights of others" (principle of legitimacy).

\footnotetext{
${ }^{1}$ UNHRC, 'Report of the Special Rapporteur on the promotion and protection of the right to freedom of opinion and expression, Frank La Rue' (16 May 2011) Session $7^{\text {th }}$ UN Doc A/HRC/17/27.

${ }^{2}$ Ofcom, "Site Blocking"' to reduce online copyright infringement - A review of sections 17 and18 of the Digital Economy Act' < http://stakeholders.ofcom.org.uk/binaries/internet/site-blocking.pdf $>$ at page 3, accessed 2 February, 2012.

${ }^{3}$ Times Newspapers Ltd (Nos 1 and 2) v the United Kingdom (App nos 3002/03 and 23676/03) (2009) ECHR 451 [27].
} 
- Third, it needs to be proven to be "necessary" and the least invasive means possible to achieve the specific aim (principles of necessity and proportionality). ${ }^{4}$

On 1 February 2011, the UK Secretary of State for Culture, Mr Jeremy Hunt asked the independent regulator Ofcom to evaluate whether sections 17 and 18 of the DEA "could work'. 5 In a crucial announcement Mr Hunt declared:

"I have no problem with the principle of blocking access to websites used exclusively for facilitating illegal downloading of content. But it is not clear whether the site blocking provisions in the Act could work in practice so I have asked Ofcom to address this question,"6

In May 2011, Ofcom published a review of sections 17 and 18 of the DEA, which concluded that the site blocking provisions would be ineffective. ${ }^{7}$

As will be seen, this paper's major argument is that taking into account the findings of the CJEU in SABAM $v$ Scarlet ${ }^{8}$ and SABAM $v$ Netlog $^{9}$, the UK government's decision to drop site-blocking plans appears appropriate. The paper examines the findings of Fox $v B T^{10}$. It contrasts such findings with the three-part cumulative test and considering the incompatibility of any site-blocking measure with the CJEU's jurisprudence, concludes that the UK could possibly be in breach of European case-law.

\section{Blocking Measures under the First-Part OF THE Special Rapporteur's Cumulative Test}

The first issue to be examined in this paper is to what extent, if any, the power to make provision about injunctions preventing access to internet locations may possibly be compatible with the first-part of the Special Rapporteur's cumulative test. There is a legal rationale for permitting an interference with Article 10(2) of the ECHR that stems from the

\footnotetext{
${ }^{4}$ UNHRC, 'Report of the Special Rapporteur on the promotion and protection of the right to freedom of opinion and expression, Frank La Rue' (16 May 2011) Session $7^{\text {th }}$ UN Doc A/HRC/17/27 at page 8.

${ }^{5}$ Department for Culture, Media and Sports, 'Ofcom to review aspects of Digital Economy Act' News Release (1 February 2011$)<$ http://www.culture.gov.uk/news/media_releases/7756.aspx $>$ accessed 4 February, 2012.

${ }^{6}$ Ibid.

7 ، ... we find that sections 17 and 18 are unlikely to be able to provide for a framework for site blocking which would be effective. We do not believe that it is possible to deliver a framework under the DEA which simultaneously meets the requirements of the copyright owners for a timely implementation of blocks and a flexible approach from service providers to tackling circumvention, with the need to respect the legitimate interests of site operators, service providers and end users' see Ofcom, "Site Blocking" to reduce online copyright infringement - A review of sections 17 and18 of the Digital Economy Act' $<$ http://stakeholders.ofcom.org.uk/binaries/internet/site-blocking.pdf $>$ at page 50, accessed 4 February, 2012.

${ }^{8}$ Case 70-10 Scarlet Extended SA v Société belge des auteurs, compositeurs et éditeurs SCRL (SABAM) [2012] ECDR 4.

${ }^{9}$ Case 360-10 Belgische Vereniging van Auteurs, Componisten en Uitgevers CVBA (SABAM) v Netlog NV [2012] ECR I-0000.

${ }^{10}$ Twentieth Century Fox Film Corp \& Ors v British Telecommunications Plc [2011] EWHC 1981 (Ch).
} 
DEA site blocking provisions. This section will critically assess whether sections 17 and 18 of the DEA respect the principles of predictability and transparency. According to the firstpart of the Special Rapporteur's cumulative test for any restriction upon the right to freedom of expression to be "prescribed by law" under Article 10(2) of the ECHR, the site blocking provisions should be drafted so that the provisions are clear and precise. ${ }^{11}$ Jeremy Hunt asked Ofcom to review the site blocking provisions. In particular, sections 17 and 18 of the DEA which give the Secretary of State the power to grant the courts the authority to compel service providers and other intermediaries, to block access to locations, which are suspected of being involved in copyright infringement. ${ }^{12}$ However, due to the lack of predictability, transparency and foreseeability inherent in the latter power, this section shows how, regardless of being "prescribed by law' in view of the Opinion of the CJEU Advocate General Cruz Villalón in $S A B A M v$ Scarlet $^{13}$ it is arguable that the UK government's elimination of the site blocking provisions seems appropriate.

\section{The CJEU's guidance in L'oreal veBay}

To begin with, in line with the CJEU in L'oreal $v$ eBay the third sentence of Article 11 of Directive 2004/48/EC read together with Article 18 of Directive 2000/31/EC permit domestic courts to require an online service provider to adopt measures that not only result in terminating contraventions, but also in precluding further violations. ${ }^{14}$

Furthermore, the CJEU observes that it is also evident from recital 23 to Directive 2004/48/EC that under the third sentence of Article 11 the conditions for the adoption of the injunctions for which the Member States need to implement are "a matter for national law', 15

Notwithstanding, as the Court elaborates, the above measures, which are "described (nonexhaustively)" in addition to any other measure that could be ordered, need to strike a fair balance between the competing interests at stake. ${ }^{16}$

\footnotetext{
${ }^{11}$ UNHRC, 'Report of the Special Rapporteur on the promotion and protection of the right to freedom of opinion and expression, Frank La Rue' (16 May 2011) Session $7^{\text {th }}$ UN Doc A/HRC/17/27 at page 8.

${ }_{12}$ Ofcom, "Site Blocking" to reduce online copyright infringement - A review of sections 17 and18 of the Digital Economy Act' < http://stakeholders.ofcom.org.uk/binaries/internet/site-blocking.pdf > at page 3, accessed 7 February, 2012.

${ }_{13}$ Advocate General's Opinion in Case 70-10 Scarlet Extended SA v Société belge des auteurs, compositeurs et éditeurs SCRL (SABAM) [2012] ECDR 4.

${ }^{14}$ Case 324/09 L'Oréal and Others [2011] ECR I-0000 [127], [132].

${ }^{15}$ Ibid [135].

${ }^{16} \mathrm{Ibid}[143]$
} 


\section{Blocking injunctions in the UK}

According to Ofcom's review, content holders in the UK already have two methods of ensuring blocking injunctions. Firstly, a court could grant an injunction compelling the alleged contravening party to immediately stop the infringing act. Secondly, they also have section 97A of the CDPA. ${ }^{17}$

However, since under the CDPA the injunction may only be granted when an infringement has already taken place Ofcom's review notes that section 97A seems to be less suitable for ensuring injunctions than the DEA. ${ }^{18}$

As stated in section 17 of the DEA:

“(1) The Secretary of State may by regulations make provision about the granting by a court of a blocking injunction in respect of a location on the internet which the court is satisfied has been, is being or is likely to be used for or in connection with an activity that infringes copyright.

(2) 'Blocking injunction' means an injunction that requires a service provider to prevent its service being used to gain access to the location." 19

In Europe there has been a significant increase in the number of decisions where the problems associated with blocking injunctions have been addressed. ${ }^{20}$ Nevertheless, taking into account the findings of the CJEU in SABAMv Scarlet $^{21}$ and SABAM v Netlog ${ }^{22}$ none of those cases appears to recognise the human rights issues raised by these orders to any greater extent than the British Fox $v B T^{23}$.

\footnotetext{
${ }^{17}$ Ofcom, "Site Blocking", to reduce online copyright infringement - A review of sections 17 and18 of the Digital Economy Act' < http://stakeholders.ofcom.org.uk/binaries/internet/site-blocking.pdf > at page 46, accessed 7 February, 2012.

${ }^{18}$ Ibid.

${ }^{19}$ Digital Economy Act 2010 section 17.

${ }^{20}$ See for example IFPI Danmark v Tele 2 A/S (Copenhagen City Court, 25 October 2006); SABAM v Tiscali SA (Brussels Court of First Instance, 29 June 2007); IFPI Danmark v DMT2 A/S (Frederiskberg Court, 29 October 2008); Bergamo Public Prosecutor's Officer v Kolmisappi (Italian Supreme Court of Cessation, 29 Sept 2009); Columbia Pictures Industries Inc v Portlane AB (Swedish Court of Appeal, 4 May 2010); Nordic Records Norway AS v Telenor ASA (Borgarting Court of Appeal, 9 February 2010); Stichting Bescherming Rechten Entertainment Industrie Nederland (BREIN) v Ziggo BV (District Court of the Hague, 19 July 2010); EMI Records (Ireland) Ltd v UPC Communications Ireland Ltd [2010] IEHC 377; Constantin Film v UPC (Commercial Court of Austria, 13 May 2011); Twentieth Century Fox Film Corp v Newzbin Ltd [2010] EWCH 608 (Ch); Twentieth Century Fox Film Corp \& Ors v British Telecommunications Plc [2011] EWHC 1981 (Ch); Twentieth Century Fox Film Corp \& Ors v British Telecommunications Plc [2011] EWHC 2714 (Ch); Dramatico Entertainment Limited and Ors v British Sky Broadcasting Limited and Ors [2012] EWHC 268 (Ch); Dramatico Entertainment Limited and Ors $v$ British Sky Broadcasting Limited and Ors [2012] EWHC 1152 (Ch).

${ }^{21}$ Case 70-10 Scarlet Extended SA v Société belge des auteurs, compositeurs et éditeurs SCRL (SABAM) [2012] ECDR 4.

${ }^{22}$ Case 360-10 Belgische Vereniging van Auteurs, Componisten en Uitgevers CVBA (SABAM) v Netlog NV [2012] ECR I-0000.

${ }^{23}$ Twentieth Century Fox Film Corp \& Ors v British Telecommunications Plc [2011] EWHC 1981 (Ch).
} 


\section{Definition of location, service provider and information society service}

Notably, in Fox $v$ BT the claimants contend that section 17 of the DEA differentiates between the location that is employed to contravene copyright, and the service provider's facility that is employed to access the location utilized to contravene copyright. ${ }^{24}$

Although not mentioned in Fox $v$ BT it is worth noting that Ofcom's review understands location as being any host connected to the internet that can connect and transmit data to another web host. ${ }^{25}$

However, in light of the analysis of whether consistent with the first-part of the Special Rapporteur's cumulative test the site blocking provisions are 'prescribed by law' under article 10(2) of the ECHR attention should be paid to the below definitions.

The explanatory notes to the DEA assert that a service provider is one relating to provision of an information society service. Moreover, an information society service is "broadly defined" as any facility "normally" supplied for remuneration at a distance through electronic equipment. Interestingly, instances of these not only include ISPs but also site providers, such as, cyberlockers. ${ }^{26}$

\section{Sections 17 and $18 \mathrm{v}$ section 97A}

On the other hand, of particular relevance is that pursuant to Ofcom's review the site blocking provisions introduce a scheme for injunctions that is "much broader" than section 97A of the CDPA. For example, under the latter a service provider needs to have actual knowledge of information about an individual employing their facility to contravene copyright. However, Ofcom notes, the knowledge or lack thereof under section 17 of the DEA is irrelevant. ${ }^{27}$

As Ofcom's review explains, the important determinant is thus whether the site "has been, is being or is likely to be used for or in connection with" copyright infringement. ${ }^{28}$

\footnotetext{
${ }^{24}$ Ibid [102].

${ }^{25}$ Ofcom, "Site Blocking" to reduce online copyright infringement - A review of sections 17 and 18 of the Digital Economy Act' < http://stakeholders.ofcom.org.uk/binaries/internet/site-blocking.pdf > at page 9, accessed 20 February, 2012.

${ }^{26}$ Explanatory notes to the Digital Economy Act 2010 [80].

${ }^{27}$ Ofcom, "Site Blocking", to reduce online copyright infringement - A review of sections 17 and18 of the Digital Economy Act' < http://stakeholders.ofcom.org.uk/binaries/internet/site-blocking.pdf $>$ at page 47, accessed 2 February, 2012.

${ }^{28}$ Ibid.
} 


\section{Problems}

First, if the injunction is formulated in very narrow terms, Ofcom's review observes that blocking access to a particular IP address may be fairly easy to bypass. Notwithstanding, if the terms “are not sufficiently precise", service providers might find themselves in a difficult position. $^{29}$

Although neither addressed in $S A B A M v$ Scarlet $^{30}$ nor in $S A B A M v$ Netlog $^{31}$ an important note here is that Ofcom's review is consistent with Villalón's Opinion in the former decision. The Advocate General explains that the Charter rights can be limited where permitted under domestic laws which are "accessible, clear and predictable". 32

It is interesting to note, however, that according to Ofcom under both the site blocking provisions and section 97A, content holders or their agents would still have to prove that the alleged contravention concerned copyright in compositions held by them. Yet, as Fox $v$ Newzbin ${ }^{33}$ evidences, this could sometimes pose a challenge. ${ }^{34}$

All things considered, to be aligned with the first-part of the Special Rapporteur's cumulative test for article 10(2) of the ECHR to be 'prescribed by law' sections 17 and 18 of the DEA need to be compatible with the principles of predictability and transparency. ${ }^{35}$ As discussed below, it is disputable that in view of Villalón's Opinion in SABAMv Scarlet $^{36}$ their elimination by the UK government seems appropriate.

\section{Site blocking provisions inconsistency with the principle of predictability}

Firstly, one might debate that in rejecting the site blocking provisions the UK government can be regarded as having made an informed decision.

\footnotetext{
${ }^{29}$ Ibid at page 48 .

${ }^{30}$ Case 70-10 Scarlet Extended SA v Société belge des auteurs, compositeurs et éditeurs SCRL (SABAM) [2012] ECDR 4.

${ }^{31}$ Case 360-10 Belgische Vereniging van Auteurs, Componisten en Uitgevers CVBA (SABAM) v Netlog NV [2012] ECR I-0000.

${ }^{32}$ Advocate General's Opinion in Case 70-10 Scarlet Extended SA v Société belge des auteurs, compositeurs et éditeurs SCRL (SABAM) [2012] ECDR 4 [96].

${ }^{33}$ Twentieth Century Fox Film Corp v Newzbin Ltd [2010] EWCH 608 (Ch).

${ }^{34}$ Ofcom, "Site Blocking" to reduce online copyright infringement - A review of sections 17 and18 of the Digital Economy Act' < http://stakeholders.ofcom.org.uk/binaries/internet/site-blocking.pdf > at page 47, accessed 1 March, 2012.

${ }^{35}$ UNHRC, 'Report of the Special Rapporteur on the promotion and protection of the right to freedom of opinion and expression, Frank La Rue' (16 May 2011) Session $7^{\text {th }}$ UN Doc A/HRC/17/27 at page 8.

${ }^{36}$ Advocate General's Opinion in Case 70-10 Scarlet Extended SA v Société belge des auteurs, compositeurs et éditeurs SCRL (SABAM) [2012] ECDR 4.
} 
As outlined above, in line with the first-part of the Special Rapporteur's cumulative test, under article 10(2) of the ECHR to be "prescribed by law'" any interference with the right to freedom of speech needs to respect the principle of predictability. ${ }^{37}$

Or put differently, as the CJEU's Advocate General recommends in SABAM v Scarlet, to conform to the ECtHR's case-law the legislation must clearly establish the circumstances under which it is applicable. ${ }^{38}$

According to Ofcom's review, section 17 of the DEA introduces a scheme for injunctions that is "much broader" than section 97A of the CDPA. ${ }^{39}$ Specifically, following section 17(2):

“'blocking injunction' means an injunction that requires a service provider to prevent its service being used to gain access to the location." 40

Moreover, a service provider is one relating to provision of an information society service and the latter is "broadly defined" as any service "normally" supplied for remuneration at a distance via electronic equipment. ${ }^{41}$

In other words, this definition seems broad enough to include any service, including email, application providers like Twitter, video-sharing sites such as Vimeo as well as search engines like Google.

Thus, considering Villalón's Opinion above the UK government's decision to reject website blocking plans appears fair. Indeed, all the more so given that in BT $v$ State Parker J expressly recognises that "section 17 does not prescribe the circumstances in which the regulations would allow an injunction to be applied for or granted by the court', ${ }^{42}$ Not to mention the impact of such measures on the free speech rights of ISPs, site operators and users.

\footnotetext{
${ }^{37}$ UNHRC, 'Report of the Special Rapporteur on the promotion and protection of the right to freedom of opinion and expression, Frank La Rue' (16 May 2011) Session $7^{\text {th }}$ UN Doc A/HRC/17/27 at page 8.

${ }_{38}$ Advocate General's Opinion in Case 70-10 Scarlet Extended SA v Société belge des auteurs, compositeurs et éditeurs SCRL (SABAM) [2012] ECDR 4 [94].

${ }^{39}$ Ofcom, "Site Blocking" to reduce online copyright infringement - A review of sections 17 and18 of the Digital Economy Act' < http://stakeholders.ofcom.org.uk/binaries/internet/site-blocking.pdf > at page 47, accessed 1 March, 2012.

${ }^{40}$ Digital Economy Act 2010 section 17(2)

${ }^{41}$ Explanatory notes to the Digital Economy Act 2010 [80].

${ }^{42}$ BT PLC and Talk Talk PLC v Secretary of State for Business Innovation and Skills and others [2011] EWHC 1021 (Admin) [51].
} 


\section{Site blocking provisions inconsistency with the principle of transparency}

Secondly, another point at which the UK government excels is the acknowledgement of the fact that significant problems arise when assessing the terms of any injunction. Indeed, as the Advocate General in SABAM v Scarlet explains, if those terms are not sufficiently clear any blocking measure could possibly be challenged as illegal. ${ }^{43}$

It has been seen earlier that consistent with the first-part of the Special Rapporteur's cumulative test for any limitation to the right to freedom of expression to be "prescribed by law', such law should comply with the principle of transparency. ${ }^{44}$

Or put differently, pursuant to Villalón's Opinion in $S A B A M v$ Scarlet $^{45}$ it is well established in the ECtHR's jurisprudence that:

"the law must indicate... the manner of its exercise with sufficient clarity... to give the individual adequate protection against arbitrary interference. ',46

It is true that peer-to-peer file-sharing seems to account for the best part of online copyright infringement. ${ }^{47}$ However, as Ofcom's review notes:

Streaming: is also a technology employed by many legal sites (e.g., BBC iPlayer and YouTube).

Cyberlockers/Cloud storage: is likewise a widely used technology that can search for and locate lawful and unlawful content such as pictures and documents.

USENET: is similar to a virtual bulletin board where again users can legally post comments and files. ${ }^{48}$

\footnotetext{
${ }^{43}$ Advocate General's Opinion in Case 70-10 Scarlet Extended SA v Société belge des auteurs, compositeurs et éditeurs SCRL (SABAM) [2012] ECDR 4 [67], [94], [95].

${ }^{44}$ UNHRC, 'Report of the Special Rapporteur on the promotion and protection of the right to freedom of opinion and expression, Frank La Rue' (16 May 2011) Session $7^{\text {th }}$ UN Doc A/HRC/17/27 at page 8.

${ }^{45}$ Advocate General's Opinion in Case 70-10 Scarlet Extended SA v Société belge des auteurs, compositeurs et éditeurs SCRL (SABAM) [2012] ECDR 4 [94].

${ }^{46}$ Kruslin v France (App no 11801/85) (1990) 12 EHRR 547 [30]; see also the Sunday Times v the United Kingdom (Series A no 30) (1979) 2 EHHR 245 [49]; Tolstoy Miloslavsky $v$ the United Kingdom (App no 18139/91) (1995) 20 EHRR 442 [37]; Rotaru v Romania (App no 28341/95) (2000) ECHR 2000-V [52]; Hasan and Chaush v Bulgaria (App no 30985/96) (2000) ECHR 2000-XI [84]; Maestri v Italy (App no 39748/98) (2004) ECHR 2004-I [30]; Sanoma Uitgevers BV v The Netherlands (App no 38224/03) (2010) ECHR 1284 [82].

${ }^{47}$ BT PLC and Talk Talk PLC v Secretary of State for Business Innovation and Skills and others [2011] EWHC 1021 (Admin) [230].

48 Ofcom, "Site Blocking" to reduce online copyright infringement - A review of sections 17 and18 of the Digital Economy Act' < http://stakeholders.ofcom.org.uk/binaries/internet/site-blocking.pdf > at page 13, accessed 5 March, 2012.
} 
In other words, those of Parker $\mathrm{J}$ in $B T v$ State "it must be remembered that $P 2 P$ is not the only means of gaining access to copyright... material. " 49

Therefore, the impact of the site blocking provisions on perfectly legitimate technologies is yet another example of why the UK's government abandonment of section 17 of the DEA seems appropriate. Let alone the negative effect that these measures could also have on innovation.

\section{Site blocking provisions inconsistency with the requirement of foreseeability}

Thirdly, as Fox $v$ Newzbin ${ }^{50}$ illustrates, a final strong point of Ofcom's review is the UK government's acceptance that considering both section 97A and the site blocking provisions the complexity involved in detecting infringing content could sometimes pose a challenge. ${ }^{51}$

According to the ECtHR's well-established case-law, in order for a restriction on the right to freedom of expression to be "prescribed by law" the requirement of foreseeability should also be satisfied. ${ }^{52}$

Put another way, as the CJEU's Advocate General observers in SABAM v Scarlet ${ }^{53}$ in light of the Strasbourg organs Leander v Sweden under Article 10(2) of the ECHR:

"the law in question must be accessible to the individual concerned and its consequences for him must also be foreseeable." "54

In Fox $v$ Newzbin ${ }^{55} 36 \mathrm{TV}$ shows are reported to be likely to be copyright-protected. Moreover, in the case of 'Music', 112 tracks are suspected to be associated with material otherwise likely to be copyright-protected. And in the case of 'Books', 48 records are considered to be likely to be copyright-protected. ${ }^{56}$

Nevertheless, the question remains as to when the term "likely" crosses the boundary of infringement. The CJEU in SABAM v Scarlet and SABAM v Netlog found that blocking

\footnotetext{
${ }^{49}$ BT PLC and Talk Talk PLC v Secretary of State for Business Innovation and Skills and others [2011] EWHC 1021 (Admin) [251].

${ }^{50}$ Twentieth Century Fox Film Corp v Newzbin Ltd [2010] EWCH 608 (Ch).

51 Ofcom, "Site Blocking"' to reduce online copyright infringement - A review of sections 17 and 18 of the Digital Economy Act' < http://stakeholders.ofcom.org.uk/binaries/internet/site-blocking.pdf > at page 47, accessed 5 March, 2012.

52 See for example Kopp v Switzerland (app no 23224/94) (1999) 27 EHRR 91 [64], [72].

${ }_{53}$ Advocate General's Opinion in Case 70-10 Scarlet Extended SA v Société belge des auteurs, compositeurs et éditeurs SCRL (SABAM) [2012] ECDR 4 [94]

${ }^{54}$ Leander $v$ Sweden (App no 9248/81) (1987) 9 EHRR 433 [50]; see also Malone v United Kingdom (App no 8691/79) (1984) 7 EHRR 14 [66].

${ }^{55}$ Twentieth Century Fox Film Corp v Newzbin Ltd [2010] EWCH 608 (Ch).

${ }^{56}$ Twentieth Century Fox Film Corp \& Ors v British Telecommunications Plc [2011] EWHC 1981 (Ch) [51].
} 
measures "might not distinguish adequately between unlawful...and lawful content", 57 Thus, one could debate that the "likely to be used for or in connection with" "58 infringement test may not necessarily recognise whether for instance mashups, bootlegs and remixes are legitimate.

Consequently, given that users would almost certainly fail to foresee what transforming copyrighted content may entail, again the UK's government removal of section 17 of the DEA appears fair. Not to mention the profoundly detrimental effects that those provisions would also have upon collaborative creativity.

\section{Incompatibility with the first-part of the Special Rapporteur's cumulative test}

This section has examined whether the power to make provision about injunctions preventing access to internet locations could possibly be consistent with the first-part of the Special Rapporteur's cumulative test. There is a legal rationale for permitting interference that stems from sections 17 and 18 of the DEA. However, the first major finding of this paper is that despite being "prescribed by law' under article 10(2) of the ECHR from the ECtHR and the CJEU's Advocate General perspective the site blocking provisions appear to be at odds with the principles of predictability, transparency and foreseeability. Thus, instead of censoring perfectly legitimate sites, neutral technologies and transformative uses of copyrighted works, an important practical implication of this section is that in the light of Villalón's Opinion in SABAM v Scarlet ${ }^{59}$ it is submitted that the UK government's show of support for freedom of speech online appears fair. It is therefore understandable why in rejecting sections 17 and 18 of the DEA Ofcom's review seems to suggest that the right to freedom of expression, innovation and creativity must be respected. Nevertheless, as discussed next, assuming that the site blocking provisions had not been rejected they would in any case have to conform to the second-part of the Special Rapporteur's cumulative test. As a result, under article 10(2) of the ECHR so as "to protect the rights of others" the site blocking provisions should also comply with the principle of legitimacy. ${ }^{60}$

\footnotetext{
${ }^{57}$ Case 70-10 Scarlet Extended SA v Société belge des auteurs, compositeurs et éditeurs SCRL (SABAM) [2012] ECDR 4 [52]; Case 360-10 Belgische Vereniging van Auteurs, Componisten en Uitgevers CVBA (SABAM) v Netlog NV [2012] ECR I-0000 [50].

${ }^{58}$ Digital Economy Act 2010 section 17(1).

${ }_{59}$ Advocate General's Opinion in Case 70-10 Scarlet Extended SA v Société belge des auteurs, compositeurs et éditeurs SCRL (SABAM) [2012] ECDR 4.

${ }^{60}$ UNHRC, 'Report of the Special Rapporteur on the promotion and protection of the right to freedom of opinion and expression, Frank La Rue' (16 May 2011) Session $7^{\text {th }}$ UN Doc A/HRC/17/27 at page 8.
} 


\section{Blocking Measures Under the Second-Part of the Special Rapporteur's Cumulative Test}

The second matter to be examined in this paper is whether conforming to the second-part of the Special Rapporteur's cumulative test the DEA site blocking provisions comply with the principle of legitimacy. ${ }^{61}$ In Fox $v$ BT Arnold J finds that the studios copyrights are "rights of others" within the meaning of article 10(2) of the ECHR. ${ }^{62}$ However, as he notes, in Fox $v$ Newzbin ${ }^{63}$ Kitchin $\mathrm{J}$ is not referred to any relevant laws and jurisprudence, which directly affect human rights. Thus, where the court becomes aware of evidence that the Convention rights of content holders other than the participants to a copyright dispute are compromised, according to Arnold $\mathrm{J}$ it is not simply empowered, but "obliged", to respect them. ${ }^{64}$ As will be discussed, in light of the CJEU SABAM v Scarlet and SABAM v Netlog for any limitation to freedom of expression to "protect the rights of others"' content holders' rights need to be fairly balanced against those of ISPs, site operators and users. ${ }^{65}$ Therefore, in contrast with Arnold J's finding this section will show why the UK government's rejection of sections 17 and 18 of the DEA seems appropriate. Indeed, this is particularly true when perfectly legitimate online speech, like employing a site with no intention of infringing upon copyright needs to be censored by the High Court but could possibly be found illegitimate by both the second-part of the Special Rapporteur's cumulative test and the CJEU's case-law.

\section{The studios' interest in Newzbin2}

To begin with, in Fox $v$ BT pursuant to Arnold $\mathrm{J}$ movies and TV shows make up about $70 \%$ of the available content through Newzbin2 whilst approximately $30 \%$ of that content comprises different types of material. ${ }^{66}$

Yet though the studios control the copyrights to many movies and TV shows distributed by Newzbin2, he notes that it is evident that other content owners are likewise "substantially affected' ' by it. ${ }^{67}$

\footnotetext{
61 Ibid.

${ }^{62}$ Twentieth Century Fox Film Corp \& Ors v British Telecommunications Plc [2011] EWHC 1981 (Ch) [164].

${ }^{63}$ Twentieth Century Fox Film Corp v Newzbin Ltd [2010] EWCH 608 (Ch).

${ }^{64}$ Twentieth Century Fox Film Corp \& Ors v British Telecommunications Plc [2011] EWHC 1981 (Ch) [183].

${ }^{65}$ Case 70-10 Scarlet Extended SA v Société belge des auteurs, compositeurs et éditeurs SCRL (SABAM) [2012] ECDR 4 [45]; Case 360-10 Belgische Vereniging van Auteurs, Componisten en Uitgevers CVBA (SABAM) v Netlog NV [2012] ECR I-0000 [43].

${ }^{66}$ Twentieth Century Fox Film Corp \& Ors v British Telecommunications Plc [2011] EWHC 1981 (Ch) [179].

67 Ibid.
} 
Of particular relevance here, however, is that the respondent claims that it would be inappropriate to grant an injunction that goes beyond the repertoire where the studios hold rights, and to compel BT to block its users from accessing any element of Newzbin2 for any purpose. $^{68}$

In particular, in support of the above BT gathers evidence from two decisions - CPI $v$ Robinson ${ }^{69}$ and Fox $v$ Newzbin ${ }^{70}$.

\section{CPI v Robinson}

First, consistent with Arnold $\mathrm{J}$ in Fox $v B T^{71}$, in CPI $v$ Robinson Scott $\mathrm{J}$ held:

“... Counsel... has sought an injunction restraining the defendants from knowingly infringing copyright in any film for the time belonging to any of the plaintiffs (meaning any member of the MPAA besides the named plaintiffs) or in respect of which any of them is for the time being the exclusive licensee... it would be wrong in principle to grant an injunction the scope of which the defendants subject to it could not know and could not discover... Experience... has underlined the very great difficulty... in ascertaining in whom copyright or exclusive rights... are... being vested... I am not prepared to extend this protection to companies who are not plaintiffs, that is... to future MPAA members. Nor am I prepared to extend this protection to cover other films,", 72

Although not mentioned in Fox $v B T$ in deciding whether to grant an injunction section 17 of the DEA states that the court needs to take account of any proof of steps taken by the content holder, or by a licensee ${ }^{73}$ and "copyright owner" has to be understood as in the CDPA. ${ }^{74}$

Yet in Fox $v$ BT the High Court is convinced that the above decision does not answer whether an injunction should be granted, but instead the scope of the injunction. ${ }^{75}$ Accordingly, Arnold $\mathrm{J}$ finds no support in CPI $v$ Robinson ${ }^{76}$ for the contention that an applicant cannot

\footnotetext{
${ }^{68}$ Ibid.

${ }^{69}$ Columbia Pictures Industries Inc v Robinson [1986] 3 All ER 338.

${ }^{70}$ Twentieth Century Fox Film Corp v Newzbin Ltd [2010] EWCH 608 (Ch).

${ }^{71}$ Twentieth Century Fox Film Corp \& Ors v British Telecommunications Plc [2011] EWHC 1981 (Ch) [180].

${ }^{72}$ Columbia Pictures Industries Inc v Robinson [1986] 3 All ER 338 [364], [365].

${ }^{73}$ Digital Economy Act 2010 section17(5)(b).

${ }^{74}$ Ibid section $17(12)$.

${ }^{75}$ Twentieth Century Fox Film Corp \& Ors v British Telecommunications Plc [2011] EWHC 1981 (Ch) [181].

${ }^{76}$ Columbia Pictures Industries Inc v Robinson [1986] 3 All ER 338.
} 
secure an injunction that goes beyond the particular copyrights found to have been contravened. ${ }^{77}$

It is interesting to note, however, that pursuant to the Court "it is commonplace for rightholders... to be granted injunctions covering the entire repertoire... even though infringements of only a small number of copyrights have been proved. ",78

Furthermore, of particular importance is that Arnold J selects Fox $v$ Newzbin ${ }^{79}$ to endorse the claim that Kitchin $\mathbf{J}$ granted injunctive relief that not only included the studios present repertoire, but "also future additions". 80

\section{Fox v Newzbin}

Secondly, in Fox $v$ BT the respondent relies on Fox $v$ Newzbin ${ }^{81}$ where Kitchin $\mathrm{J}$ declines to grant an injunction extending beyond the studios' copyrights repertoire on the grounds he gives at [135]. ${ }^{82}$

Notwithstanding, as Arnold $\mathrm{J}$ observes, in Fox $v$ Newzbin this issue is not disputed before Kitchin $\mathrm{J}$ in any depth. ${ }^{83}$ However, in view of the analysis of whether under Article 10(2) of the ECHR the site blocking provisions comply with the second-part of the Special Rapporteur's cumulative test, the Court's next finding becomes crucial.

According to Arnold J, it appears evident from Fox $v$ Newzbin ${ }^{84}$ that Kitchin $\mathrm{J}$ is not referred to any of the case-law relevant to the Human Rights Act 1998. Thus, where the court appreciates from such evidence that the Convention rights of individuals other than the participants are involved, Arnold J finds that it is not simply authorized, but 'obliged', to respect them. ${ }^{85}$

Notably, this seems to contradict SABAM v Scarlet and SABAM v Netlog where the CJEU notes that there is nothing under Article 17(2) of the Charter or the Court's jurisprudence to

\footnotetext{
${ }^{77}$ Twentieth Century Fox Film Corp \& Ors v British Telecommunications Plc [2011] EWHC 1981 (Ch) [181].

78 Ibid.

${ }^{79}$ Twentieth Century Fox Film Corp v Newzbin Ltd [2010] EWCH 608 (Ch).

${ }^{80}$ Twentieth Century Fox Film Corp \& Ors v British Telecommunications Plc [2011] EWHC 1981 (Ch) [181].

${ }^{81}$ Twentieth Century Fox Film Corp v Newzbin Ltd [2010] EWCH 608 (Ch).

${ }^{82}$ Twentieth Century Fox Film Corp \& Ors v British Telecommunications Plc [2011] EWHC 1981 (Ch) [182].

${ }^{83}$ Ibid [183].

${ }^{84}$ Twentieth Century Fox Film Corp v Newzbin Ltd [2010] EWCH 608 (Ch).

${ }^{85}$ Twentieth Century Fox Film Corp \& Ors v British Telecommunications Plc [2011] EWHC 1981 (Ch) [183].
} 
indicate that intellectual property rights are absolute and consequently must always be protected. $^{86}$

As Arnold J elaborates, the studios' rights are being violated on an enormous scale. Thus he is satisfied that they have a "sufficient interest" to justify the power to grant the order sought. 87

Nevertheless, while the injunction will likewise benefit other content owners, consistent with Arnold $\mathbf{J}$ this is not a strong enough reason for declining injunctive relief. As the Court curiously put it, "it is immaterial that they have not formally joined in the application". ${ }^{88}$

Against this background, although Arnold J finds that "the order would potentially prevent BT subscribers from making use of Newzbin2 for non-infringing uses" he nevertheless concludes that these non-infringing purposes are de minimis. ${ }^{89}$

Again this is also inconsistent with SABAM v Scarlet and SABAM v Netlog where the CJEU held that the legality of blocking measures also depends on their impact upon three key elements: exceptions to copyright, public domain material, and free content. ${ }^{90}$

Overall, according to the second-part of the Special Rapporteur's cumulative test, sections 17 and 18 of the DEA should be enforced with the principle of legitimacy respect. ${ }^{91}$ Thus, despite protecting the "rights of others" the below discussion demonstrates why following $S A B A M v$ Scarlet $^{92}$ and SABAM v Netlog ${ }^{93}$ the UK government's refusal to implement the site blocking provisions appears appropriate.

\footnotetext{
${ }^{86}$ Case 70-10 Scarlet Extended SA v Société belge des auteurs, compositeurs et éditeurs SCRL (SABAM) [2012] ECDR 4 [43]; Case 360-10 Belgische Vereniging van Auteurs, Componisten en Uitgevers CVBA (SABAM) v Netlog NV [2012] ECR I-0000 [41].

${ }^{87}$ Twentieth Century Fox Film Corp \& Ors v British Telecommunications Plc [2011] EWHC 1981 (Ch) [185].

${ }^{88}$ Ibid.

${ }^{89}$ Ibid [186].

${ }^{90}$ Case 70-10 Scarlet Extended SA v Société belge des auteurs, compositeurs et éditeurs SCRL (SABAM) [2012] ECDR 4 [52]; Case 360-10 Belgische Vereniging van Auteurs, Componisten en Uitgevers CVBA (SABAM) v Netlog NV [2012] ECR I-0000 [50].

${ }^{91}$ UNHRC, 'Report of the Special Rapporteur on the promotion and protection of the right to freedom of opinion and expression, Frank La Rue' (16 May 2011) Session $7^{\text {th }}$ UN Doc A/HRC/17/27 at page 8.

${ }^{92}$ Case 70-10 Scarlet Extended SA v Société belge des auteurs, compositeurs et éditeurs SCRL (SABAM) [2012] ECDR 4.

${ }^{93}$ Case 360-10 Belgische Vereniging van Auteurs, Componisten en Uitgevers CVBA (SABAM) v Netlog NV [2012] ECR I-0000.
} 


\section{Covering the entire repertoire?}

Firstly, how persuasive is Arnold J's finding that "it is commonplace for rightholders ... to be granted injunctions covering the entire repertoire... even though infringements of only a small number of copyrights have been proved. ",94

In Mustafa $v$ Sweden the ECtHR held that under Article 10 of the ECHR the freedom to receive information is not only applicable to speech on matters of public concern, but involves cultural expressions in addition to "pure entertainment".95

As outlined above, in Fox $v$ BT the respondent relies upon Fox $v$ Newzbin ${ }^{96}$ in which Kitchin J opposes granting an injunction going beyond the studios' copyrights repertoire on the grounds he provides at [135]. ${ }^{97}$ Nevertheless, the High Court finds that in Fox v Newzbin this issue is not disputed by Kitchin $\mathrm{J}$ in any depth. ${ }^{98}$

Yet in Fox $v B T^{99}$ what Arnold $\mathrm{J}$ regrettably appears to disregard is the fact that the studios request an injunction broader in scope where injunctive relief is more troublesome.

Or put differently, consistent with Kitchin J:

"... the claimants are seeking an injunction to restrain activities in relation to all binary and all text materials in respect of which they own no rights. ${ }^{, 100}$

Indeed, this is interesting because Arnold J's finding is at odds with SABAM $v$ Scarlet and SABAM v Netlog where the CJEU found that since such an injunction "is intended to protect not only existing works" it can no longer be deemed to respect the fair balance between copyright protection, and the freedom for ISP's to conduct their business. ${ }^{101}$

\footnotetext{
${ }^{94}$ Twentieth Century Fox Film Corp \& Ors v British Telecommunications Plc [2011] EWHC 1981 (Ch) [181].

${ }^{95}$ Khurshid Mustafa and Tarzibachi v Sweden (App no 23883/06) (2008) ECHR 1710 [44].

${ }^{96}$ Twentieth Century Fox Film Corp v Newzbin Ltd [2010] EWCH 608 (Ch).

${ }^{97}$ Twentieth Century Fox Film Corp \& Ors v British Telecommunications Plc [2011] EWHC 1981 (Ch) [182].

98 Ibid[183].

99 Ibid.

${ }^{100}$ Twentieth Century Fox Film Corp v Newzbin Ltd [2010] EWCH 608 (Ch) [135].

${ }^{101}$ Case 70-10 Scarlet Extended SA v Société belge des auteurs, compositeurs et éditeurs SCRL (SABAM) [2012] ECDR 4 [47], [49]; Case 360-10 Belgische Vereniging van Auteurs, Componisten en Uitgevers CVBA (SABAM) v Netlog NV [2012] ECR I-0000 [45], [47].
} 
Thus, it is understandable why, following Ofcom's review the UK government suggests that as ownership of copyright would still need to be proven the DEA site blocking provisions can make this all the more difficult. ${ }^{102}$

\section{Future additions to the repertoire}

Secondly, in Fox $v$ BT the High Court regards Fox $v$ Newzbin ${ }^{103}$ as authority for the contention that Kitchin $\mathbf{J}$ granted an injunction that not only included the studios' present repertoire, but "also future additions". 104

It is true that according to well-established ECtHR case-law - KUv Finland:

"although... users of telecommunications and internet services must have a guarantee that their own privacy and freedom of expression will be respected, such guarantee cannot be absolute and must yield on occasion to other legitimate imperatives such as the prevention and disorder of crime or the protection of the rights and freedoms of others." "105

However, again it is worth emphasizing that despite the fact that Fox $v B T$ remains very relevant, Arnold J's finding in the above passage regarding the injunctive relief process is at best objectionable and at worst entirely inconsistent with the CJEU's case-law.

Indeed, all the more so given that in SABAM v Scarlet and SABAM v Netlog the CJEU explicitly recognizes that such an injunction "...has no limitation in time, is directed at all future infringements and is intended to protect not only existing, but also future works that have not yet been created", 106

Accordingly, as the CJEU elaborates, in the present case, once more it must be concluded that the injunction can no longer be deemed to respect the fair balance between copyright protection, and the freedom for ISP's to conduct their business. ${ }^{107}$

\footnotetext{
102 Ofcom, "Site Blocking" to reduce online copyright infringement - A review of sections 17 and18 of the Digital Economy Act' < http://stakeholders.ofcom.org.uk/binaries/internet/site-blocking.pdf > at page 47, accessed 17 March, 2012.

${ }_{103}$ Twentieth Century Fox Film Corp v Newzbin Ltd [2010] EWCH 608 (Ch).

${ }^{104}$ Twentieth Century Fox Film Corp \& Ors v British Telecommunications Plc [2011] EWHC 1981 (Ch) [181].

${ }^{105} \mathrm{KU} v$ Finland (App no 2878/02) (2009) 48 EHRR 52 [49].

${ }^{106}$ Case 70-10 Scarlet Extended SA v Société belge des auteurs, compositeurs et éditeurs SCRL (SABAM) [2012] ECDR 4 [47]; Case 360-10 Belgische Vereniging van Auteurs, Componisten en Uitgevers CVBA (SABAM) v Netlog NV [2012] ECR I-0000 [45].

${ }^{107}$ Case 70-10 Scarlet Extended SA v Société belge des auteurs, compositeurs et éditeurs SCRL (SABAM) [2012] ECDR 4 [49]; Case 360-10 Belgische Vereniging van Auteurs, Componisten en Uitgevers CVBA (SABAM) v Netlog NV [2012] ECR I-0000 [47].
} 
Taken together, in light of the second-part of the Special Rapporteur's cumulative test, as Ofcom's review stresses, one could therefore argue that keeping in mind sections 17 and 18 of the DEA this balance seems to be extremely difficult to strike for many courts in the vast majority of cases. ${ }^{108}$

\section{How to avoid being vexed twice}

Thirdly, in Fox $v$ BT Arnold J finds in paragraph 185 that "it is immaterial" that other content owners who could also benefit from the order "have not formally joined in the application " 109 regrettably however without any solid evidence to support his claim.

There is little doubt that intellectual property protection is certainly enshrined within Article 17(2) of the Charter. ${ }^{110}$ As SABAM v Scarlet and SABAM v Netlog explain:

"there is, however, nothing whatsoever in the wording of that provision or in the Court's case-law to suggest that that right is inviolable and must for that reason be absolutely protected.",111

As discussed above, according to the Court in Fox $v$ BT it is evident that the studios' rights are being contravened on an enormous scale. Thus Arnold $\mathbf{J}$ is satisfied that they have a "sufficient interest" to justify the power to grant injunctive relief. ${ }^{112}$

Yet, as the ECtHR acknowledged in Lindon v France:

“... even where a statement amounts to a value judgment, there must exist a sufficient factual basis to support it, failing which it will be excessive. "113

In Media v Adams, the Patents County Court crucially observes that the purpose of subsection 102(1) of the CDPA is to protect respondents from being sued twice over the same issue. ${ }^{114}$

\footnotetext{
108 Ofcom, "Site Blocking" to reduce online copyright infringement - A review of sections 17 and18 of the Digital Economy Act' < http://stakeholders.ofcom.org.uk/binaries/internet/site-blocking.pdf > at page 49, accessed 17 March, 2012.

${ }_{109}$ Twentieth Century Fox Film Corp \& Ors v British Telecommunications Plc [2011] EWHC 1981 (Ch)[185].

${ }^{110}$ Case 70-10 Scarlet Extended SA v Société belge des auteurs, compositeurs et éditeurs SCRL (SABAM) [2012] ECDR 4 [43]; Case 360-10 Belgische Vereniging van Auteurs, Componisten en Uitgevers CVBA (SABAM) v Netlog NV [2012] ECR I-0000 [41].

111 Ibid.

${ }^{112}$ Twentieth Century Fox Film Corp \& Ors v British Telecommunications Plc [2011] EWHC 1981 (Ch) [185].

${ }^{113}$ Lindon, Otchakovsky-Laurens and July v France (App no21279/02, 36448/02) (2008) 46 EHRR 35 [55].

${ }^{114}$ Media CAT Ltd v Adams [2011] EWPCC 006 [79].
} 
Or put differently, in Birss $\mathrm{J}$ words, “it seems likely, therefore, that a court will expect claimants to take considerable steps to identify other persons with rights before it will grant permission to proceed without their being joined', 115

Indeed, despite Arnold J's finding the non-derogable right not be tried or punished twice is a minimum guarantee of the accussed's right to a fair trial under Article 4 of Protocol No 7 to the ECHR. ${ }^{116}$

\section{Incompatibility with the second-part of the Special Rapporteur's cumulative test}

This section has examined whether the DEA site blocking provisions could respect the second-part of the Special Rapporteur's cumulative test. Although according to Fox $v$ BT, the studios copyrights are "rights of others" under article 10(2) of the ECHR ${ }^{117}$ the second major finding of this paper is that from both the ECtHR and the CJEU perspective sections 17 and 18 of the DEA might possibly be inconsistent with the principle of legitimacy. Yet instead of extending injunctive relief to entire repertoires, future additions and non-claimants another significant practical implication of this section is that in light of SABAM $v$ Scarlet and SABAM $v$ Netlog the UK could be in breach of European case-law. Indeed, as the CJEU suggests, because the use of exempted, public domain or creative commons licensed material is non-infringing ${ }^{118}$, no court should ever be allowed to restrict upon the notion of striking a fair balance between copyright holders' interests and those of ISPs, site operators and users. Thus it is easy to justify why in conforming to Ofcom's review the removal by the UK government of the DEA's ability to block artistic content on the web seems appropriate. However, as will be discussed next, in order to solve the above unresolved problem consistent with the third-part of the Special Rapporteur's cumulative test, the real question is whether the power to make provision about injunctions preventing access to internet locations complies with the principles of necessity and proportionality. ${ }^{119}$

\footnotetext{
115 Ibid.

${ }^{116}$ Protocol No 7 to the Convention for the Protection of Human Rights and Fundamental Freedoms as amended by Protocol No 11 article 4 - Right not to be tried or punished twice: (1) No one shall be liable to be tried or punished again in criminal proceedings under the jurisdiction of the same State for an offence for which he has already been finally acquitted or convicted in accordance with the law and penal procedure of that State; (2) The provisions of the preceding paragraph shall not prevent the reopening of the case in accordance with the law and penal procedure of the State concerned, if there is evidence of new or newly discovered facts, or if there has been a fundamental defect in the previous proceedings, which could affect the outcome of the case; (3) No derogation from this Article shall be made under Article 15 of the Convention.

${ }^{117}$ Twentieth Century Fox Film Corp \& Ors v British Telecommunications Plc [2011] EWHC 1981 (Ch) [164].

${ }^{118}$ Case 70-10 Scarlet Extended SA v Société belge des auteurs, compositeurs et éditeurs SCRL (SABAM) [2012] ECDR 4 [52]; Case 360-10 Belgische Vereniging van Auteurs, Componisten en Uitgevers CVBA (SABAM) v Netlog NV [2012] ECR I-0000 [50].

${ }^{119}$ UNHRC, 'Report of the Special Rapporteur on the promotion and protection of the right to freedom of opinion and expression, Frank La Rue' (16 May 2011) Session $7^{\text {th }}$ UN Doc A/HRC/17/27 at page 8.
} 


\section{Blocking Measures under the Third-Part of THE Special Rapporteur's Cumulative Test}

In line with the third-part of the Special Rapporteur's cumulative test the next issue to be considered is whether the site blocking provisions conform to the principles of necessity and proportionality. ${ }^{120}$ Ofcom's review notes that under the DEA, content holders expect the legal system to result in injunctions coming into operation within hours after an application being made. This demonstrates the concern that they have over the sudden loss of value from unlawfully streaming live content and from the urgent need to restrict access to pre-release material. ${ }^{121}$ However, as Ofcom elaborates, due to the speed at which site operators adopt bypass mechanisms a long period between an application being approved and a block being performed decreases the effectiveness of the site blocking provisions. Thus, as Ofcom adds, it is unclear whether injunctive relief offers the remedy sought by content holders in terms of both its speed and flexibility. ${ }^{122}$ In Fox $v$ BT Arnold J finds that it is "necessary" and "proportionate"' to block Newzbin2 as the Article 1 First Protocol rights of the studios not only override the Article 10 rights of BT but also those of users and operators of Newzbin2. ${ }^{123}$ Notwithstanding, due to the ineffectiveness, severity and lack of procedural fairness of any blocking measure, this section argues, how considering the third-part of Special Rapporteur's cumulative test as well as SABAM v Scarlet ${ }^{124}$ and SABAM v Netlog ${ }^{125}$ the UK government's elimination of the site blocking provisions appears fair.

\section{The conflict from Fox $v$ BT perspective}

To begin with, in Fox $v$ BT pursuant to the High Court, it is preferable to adopt the view taken by the studios, inter alia, for the following reasons:

First, under Article 1 of the First Protocol the studios' copyrights are protected property rights. ${ }^{126}$

Secondly, the right to freedom of expression is also engaged under Article 10(1). It applies regarding BT's clients' right to receive information. ${ }^{127}$ Notably, this is consistent with

\footnotetext{
${ }^{120}$ Ibid.

${ }^{121}$ Ofcom, "Site Blocking" to reduce online copyright infringement - A review of sections 17 and18 of the Digital Economy Act' < http://stakeholders.ofcom.org.uk/binaries/internet/site-blocking.pdf > at page 47, accessed 22 March, 2012.

122 Ibid.

${ }^{123}$ Twentieth Century Fox Film Corp \& Ors v British Telecommunications Plc [2011] EWHC 1981 (Ch) [200].

${ }^{124}$ Case 70-10 Scarlet Extended SA v Société belge des auteurs, compositeurs et éditeurs SCRL (SABAM) [2012] ECDR 4.

${ }^{125}$ Case 360-10 Belgische Vereniging van Auteurs, Componisten en Uitgevers CVBA (SABAM) v Netlog NV [2012] ECR I-0000.

${ }^{126}$ Twentieth Century Fox Film Corp \& Ors v British Telecommunications Plc [2011] EWHC 1981 (Ch) [164].

127 Ibid.
} 
SABAM $v$ Scarlet and SABAM $v$ Netlog although in contrast to Arnold $\mathrm{J}$ the CJEU finds that blocking measures could not only contravene users' right to receive information but also their right to personal data protection. ${ }^{128}$

Thirdly, the studios' copyrights are "rights of others" as contained in Article 10(2). ${ }^{129}$

Fourthly, when Article 10 and Article 8 ECHR rights are engaged the High Court finds In re $S^{130}$ to be applicable where a balance needs to be struck between Article 10 and Article 1 of the First Protocol. ${ }^{131}$

Or put differently:

"(i) neither Article as such has precedence over the other; (ii) where the values under the two Articles are in conflict, an intense focus on the comparative importance of the specific rights being claimed in the individual case is necessary; (iii) the justifications for interfering with or restricting each right must be taken into account; (iv) finally, the proportionality test - or "ultimate balancing test" - must be applied to each. ",132

Fifthly, in the copyright context, the above balance is mainly struck by the CDPA although the court needs to take account of freedom of expression considering both Ashdown $v$ Telegraph ${ }^{133}$ and Promusicae v Telefonica ${ }^{134} .{ }^{135}$

Accordingly, Arnold $\mathrm{J}$ turns to the evaluation of the effectiveness and proportionality of the order.

\section{Effectiveness of the order sought}

On one hand, in Fox $v$ BT the evidence demonstrates that the operators of Newzbin2 have "at least two" circumvention tools to allow users to bypass BT's block. ${ }^{136}$ However, in view of the analysis of whether the site blocking provisions comply with the Special Rapporteur's principles of necessity and proportionality it is important to note Arnold J's next finding.

\footnotetext{
128 Case 70-10 Scarlet Extended SA v Société belge des auteurs, compositeurs et éditeurs SCRL (SABAM) [2012] ECDR 4 [51]; Case 36010 Belgische Vereniging van Auteurs, Componisten en Uitgevers CVBA (SABAM) v Netlog NV [2012] ECR I-0000 [49].

${ }^{129}$ Twentieth Century Fox Film Corp \& Ors v British Telecommunications Plc [2011] EWHC 1981 (Ch) [164].

${ }^{130}$ In re S (FC) (a child) (Appellant) [2004] UKHL 47.

${ }^{131}$ Twentieth Century Fox Film Corp \& Ors v British Telecommunications Plc [2011] EWHC 1981 (Ch) [164].

132 Ibid.

${ }^{133}$ Ashdown v Telegraph Group Ltd [2002] Ch 149.

${ }^{134}$ Case 275/06 Productores de Musica de Espana (Promusicae) v Telefonica de Espana SAU [2008] ECR I-271.

${ }^{135}$ Twentieth Century Fox Film Corp \& Ors v British Telecommunications Plc [2011] EWHC 1981 (Ch) [164].

${ }^{136}$ Ibid [192].
} 
According to the High Court, it is neither necessary nor adequate to describe these bypass mechanisms in any detail. ${ }^{137}$ As Arnold $\mathrm{J}$ observes, injunctive relief may be effectively granted for, inter alia, the following reasons.

First, it appears probable that circumvention will compel most users to gain additional expertise. Nevertheless, of particular relevance is that "even assuming that they all have the ability to acquire such expertise" Arnold $\mathrm{J}$ is satisfied that "it does not follow that they will all wish to expend the time and effort required." 138

Secondly, consistent with the Court circumvention is likely to result in lower quality downloads and slower operation. ${ }^{139}$

Thirdly, Arnold J finds support in BT and TalkTalk $v$ State ${ }^{140}$ for the proposition that although "... technical means of avoiding detection are available... the central difficulty of this argument is that it rests upon assumptions about human behaviour. ,"141

Finally, the Court elaborates "the order would be justified even if it only prevented access to Newzbin 2 by a minority of users. ",142

Although not touched upon in Fox $v B T$ it is however worth remembering that in L'oreal $v$ eBay the CJEU found that the domestic rules for the enforcement of injunctions must be devised so that the aim pursued by Directive 2004/48 may be attained. ${ }^{143}$ Or put differently, pursuant to the Court these rules need to respect the principle of effectiveness. ${ }^{144}$

\footnotetext{
${ }^{137}$ Ibid.

${ }^{138}$ Ibid [194].

${ }^{139}$ Ibid [195].

${ }^{140}$ BT PLC and Talk Talk PLC v Secretary of State for Business Innovation and Skills and others [2011] EWHC 1021 (Admin).

${ }^{141}$ Twentieth Century Fox Film Corp \& Ors v British Telecommunications Plc [2011] EWHC 1981 (Ch) [197].

142 Ibid [198].

${ }^{143}$ Case 324/09 L'Oréal and Others [2011] ECR I-0000 [136].

144 Ibid.
} 


\section{Proportionality of the order sought}

On the other hand, in Fox $v$ BT Arnold J finds that injunctive relief is "proportionate',. ${ }^{145}$

According to Arnold J:

"It is necessary... to protect the Article 1 First Protocol rights of the Studios and other copyright owners. Those interests clearly outweigh the Article 10 rights of the users of Newzbin2, and... the Article 10 rights of the operators of Newzbin2. They also outweigh BT's own Article 10 rights. "146

Yet this is inconsistent with Ofcom's review. Indeed, where there is a threat to the legitimate interests of other operators, say, those sharing the same IP address at the affected location, Ofcom suggests that the Court needs to determine what effect a block could have not only upon these individuals but also other users. ${ }^{147}$

Interestingly, Ofcom's view is reinforced by SABAM v Scarlet and SABAM v Netlog where the CJEU held that domestic measures taken to protect content owners, must strike the right balance between copyright protection and the protection of fundamental rights of people affected by them (Promusicae $v$ Telefonica $\left.{ }^{148}\right) .{ }^{149}$

That said in Fox $v$ BT the ISP claims that the injunction should require the studios to notify specific URLs regarding the specific NZBs files catalogued by Newzbin2 that correspond to unauthorized copies of specific copyright compositions. ${ }^{150}$ However, as this order requires the studios to spend a great deal of time, effort, and money in passing large URL records to BT daily, Arnold J finds that it "would not be proportionate"'. 151

Overall, consistent with the third-part of the Special Rapporteur's cumulative test, the factors to be considered when assessing the necessity and proportionality of blocking provisions include their effectiveness, severity and procedural fairness. ${ }^{152}$ As shown below, in light of

\footnotetext{
${ }^{145}$ Twentieth Century Fox Film Corp \& Ors v British Telecommunications Plc [2011] EWHC 1981 (Ch) [200].

${ }^{146}$ Ibid.

147 Ofcom, "Site Blocking" to reduce online copyright infringement - A review of sections 17 and18 of the Digital Economy Act' < http://stakeholders.ofcom.org.uk/binaries/internet/site-blocking.pdf $>$ at page 48, accessed 24 March, 2012.

${ }_{148}$ Case 275/06 Productores de Musica de Espana (Promusicae) v Telefonica de Espana SAU [2008] ECR I-271 [62-68].

${ }^{149}$ Case 70-10 Scarlet Extended SA v Société belge des auteurs, compositeurs et éditeurs SCRL (SABAM) [2012] ECDR 4 [45]; Case 360-10 Belgische Vereniging van Auteurs, Componisten en Uitgevers CVBA (SABAM) v Netlog NV [2012] ECR I-0000 [43].

${ }^{150}$ Twentieth Century Fox Film Corp \& Ors v British Telecommunications Plc [2011] EWHC 1981 (Ch) [201].

151 Ibid.

${ }^{152}$ UNHRC, 'Report of the Special Rapporteur on the promotion and protection of the right to freedom of opinion and expression, Frank La Rue' (16 May 2011) Session $7^{\text {th }}$ UN Doc A/HRC/17/27 at page 8.
} 
well-established CJEU case-law it is submitted that their rejection by the UK government seems fair.

\section{Effectiveness of the site blocking provisions}

Firstly, the main problem of Fox $v B T$ is that rather than following the expert evidence according to Arnold $\mathrm{J}$ the order sought is considered to be an effective relief. For example, in paragraph 192 the evidence demonstrates that the operators of Newzbin2 have "at least two" ways of enabling users to circumvent BT's block. ${ }^{153}$ However, the High Court held that it is not necessary or adequate grounds to examine the likely effectiveness of these bypass mechanisms. ${ }^{154}$

It is firmly rooted in the ECtHR's jurisprudence that "the Convention is intended to guarantee not rights that are theoretical or illusory but rights that are practical and effective. ",155

As discussed above, although circumvention will require most users to gain additional expertise the Court finds that "it does not follow that they will all wish to expend the time and effort required." 156 Regrettably, however, Arnold J makes such a claim without the need for evidence. Yet this is certainly surprising since Fox $v$ BT was delivered in July 2011 that is after the publication of Ofcom's review of sections 17 and 18 of the DEA in May 2011.

Or put differently, as the latter document found:

"Circumvention of a block is technically a relatively trivial matter irrespective of which of the techniques used... It...does not require a particularly high level of skill or expertise."157

Therefore, despite Arnold J's finding an impartial court could have concluded that the ineffectiveness of blocking measures is yet another piece for regarding the UK government's destruction of the blocking provisions puzzle as remarkable. Indeed, this is particularly true

\footnotetext{
${ }^{153}$ Twentieth Century Fox Film Corp \& Ors v British Telecommunications Plc [2011] EWHC 1981 (Ch) [192]. ${ }^{154}$ Ibid.

${ }^{155}$ See for example Airey $v$ Ireland (App no 6289/73) (1979) 2 EHRR 305 [24]; Belgian Linguistic Case (App no 1474/62, App no 1677/62, App no 1691/62, App no 1769/63, App no 1994/63, App no 2126/64) (1968) 1EHRR 252 [3-4]; Golder v UK (App no 4451/70) (1975) 1 EHRR 524 [35]; Luedicke, Belkacem and Koç v Federal Republic of Germany (App no 6210/73, App no 6877/75, App no 7132/75) (1978) 2 EHRR 149 [42]; Marckx v Belgium (App no 6833/74) (1979) 2 EHRR 330 [31].

${ }^{156}$ Twentieth Century Fox Film Corp \& Ors v British Telecommunications Plc [2011] EWHC 1981 (Ch) [194].

157 Ofcom, "Site Blocking", to reduce online copyright infringement - A review of sections 17 and18 of the Digital Economy Act' < http://stakeholders.ofcom.org.uk/binaries/internet/site-blocking.pdf > at page 51, accessed 1 May, 2012.
} 
when in L'oreal v eBay the CJEU held that in view of Article 3(2) of Directive 2004/48 such measures have to be "effective", and "dissuasive". 158

\section{Severity of the site blocking provisions}

Secondly, in Fox v BT the High Court also finds that it is "necessary" and "proportionate" to grant injunctive relief as the Article 1 First Protocol rights of the studios clearly override the Article 10 rights of $\mathrm{BT}$ and those of users and operators of Newzbin2. ${ }^{159}$ However, the regrettable fact remains that again Arnold J provides no evidence which can be relied upon to support his claim.

As the Strasbourg organs held in Guerra $v$ Italy, under article 10(2) of the ECHR guaranteeing freedom of expression "basically prohibits a government from restricting a person from receiving information that others wish or may be willing to impart to him. ",160

It is true that consistent with Arnold $\mathrm{J}$ in Fox $v B T$ the problem of online copyright infringement is "eloquently described by Charleton $J$ " in EMI $v U P C C^{161} .{ }^{162}$ It is worth noting nevertheless that upon the question of proportionality of blocking measures Charleton $\mathrm{J}$ of the Irish High Court wrote:

"I am not convinced... that any solution based on blocking... is reasonable...it would not be in accordance with the principle of proportionality to use a blunt instrument for the deterrence, or rendering impossible, of illegal activity, when the effect of that would inevitably lead to the infringement on the right of communication through the internet. "163

Thus considering the third-part of the Special Rapporteur's cumulative test one might debate that in rejecting the site blocking provisions the UK government arrives at a judicious decision. Indeed, this is particularly the case when in SABAM v Scarlet and SABAM v Netlog the CJEU found that as an injunction order may not differentiate properly between unlicensed

\footnotetext{
${ }^{158}$ Case 324/09 L'Oréal and Others [2011] ECR I-0000 [136].

${ }^{159}$ Twentieth Century Fox Film Corp \& Ors v British Telecommunications Plc [2011] EWHC 1981 (Ch) [200].

${ }^{160}$ Guerra and Others v Italy (App no 14967/89) (1998) 26 EHRR 357 [53].

${ }^{161}$ EMI Records (Ireland) Ltd v UPC Communications Ireland Ltd [2010] IEHC 377.

${ }^{162}$ Twentieth Century Fox Film Corp \& Ors v British Telecommunications Plc [2011] EWHC 1981 (Ch) [19].

${ }^{163}$ EMI Records (Ireland) Ltd v UPC Communications Ireland Ltd [2010] IEHC 377 [29].
} 
and licensed copyrighted material, "its introduction could lead to the blocking of lawful communications', 164

\section{A less invasive alternative than the site blocking provisions}

Thirdly, another problem that arises in Fox $v$ BT is that BT disputes that the injunction should compel the studios to notify them of all URLs that relate to the specific NZB files listed by Newzbin2 that correspond to unauthorized copies of specific copyright compositions. ${ }^{165}$ However, Arnold $\mathrm{J}$ finds such an order to be disproportionate or impracticable since it would oblige the Studios to devote considerable effort and resources in notifying extensive catalogues of URLs to BT daily. ${ }^{166}$

Yet, limitations to a defendant's rights are always required to respect and adhere to the "strict necessity"' test or the least invasive means condition. A well established part of Strasbourg organs' case-law. ${ }^{167}$

It is worth stressing that if the UK government wants to implement a site blocking scheme, Ofcom's review recommends that further research be conducted to detect and assess "alternative legal frameworks" which could be more suitable. Specifically, Ofcom's review suggests complementary measures, such as, search engine de-listing, squeezing advertising revenues, but perhaps most relevantly notice/take-down systems. ${ }^{168}$

Crucially, in L'oreal v eBay the Advocate General observes that in Finland, for instance, in light of Directive 2000/31/EC, a hosting service provider is compelled to eliminate information stored on the system only after receipt of a valid notification of copyright infringement and the user has the ability to challenge the removal within two weeks. ${ }^{169}$

In other words, as expressly acknowledged by the ECtHR in Lentia v Austria:

\footnotetext{
${ }^{164}$ Case 70-10 Scarlet Extended SA v Société belge des auteurs, compositeurs et éditeurs SCRL (SABAM) [2012] ECDR 4 [52]; Case 360-10 Belgische Vereniging van Auteurs, Componisten en Uitgevers CVBA (SABAM) v Netlog NV [2012] ECR I-0000 [50].

${ }^{165}$ Twentieth Century Fox Film Corp \& Ors v British Telecommunications Plc [2011] EWHC 1981 (Ch) [201].

${ }^{166}$ Ibid.

${ }^{167}$ See for example Marcello Viola v Italy (App no 45106/04) (2006) ECHR 2006-XI [62].

168 Ofcom, "Site Blocking" to reduce online copyright infringement - A review of sections 17 and18 of the Digital Economy Act' < http://stakeholders.ofcom.org.uk/binaries/internet//ite-blocking.pdf > at page 49, accessed 2 May, 2012.

${ }^{169}$ Advocate General's Opinion in Case 324/09 L'Oréal and Others [2011] ECR I-0000 [159].
} 
“... above all, it cannot be argued that there are no equivalent less restrictive solutions. ",170

Taken together both, the less restrictive alternative sought by BT and Ofcom's complementary measures, once more the UK government's elimination of sections 17 and 18 of the DEA seems fair.

\section{Incompatibility with the third-part of the Special Rapporteur's cumulative test}

This section has analysed whether the DEA site blocking provisions could conform to the third-part of the Special Rapporteur's cumulative test. Since the Article 1 First Protocol rights of the studios not only clearly offset the Article 10 rights of BT but also those of the operators and the users of Newzbin2 in Fox $v$ BT Arnold $\mathbf{J}$ finds that it is "necessary" and "proportionate"' to block it. ${ }^{171}$ However, given the ineffectiveness of blocking measures, their impact on Article 10 Convention rights and the studios' ability to minimally intrude on free speech, the third major finding of this paper is that sections 17 and 18 of the DEA might possibly be incompatible with the principles of necessity and proportionality. Indeed, all the more so since according to the CJEU L'oreal v eBay injunctions must be "effective", "dissuasive", and "proportionate", and cannot lead to barriers to lawful trade. ${ }^{172}$ Thus, another significant practical implication that arises from this section is that again the UK could be at odds with European case-law. It is therefore understandable why, in assessing the necessity and proportionality of the site blocking provisions Ofcom's review recommends that they are removed. ${ }^{173}$ However, as discussed in the following section, under Article 10(2) of the ECHR taking into account the findings of Section I, Section II and Section III, the last important area of consideration will be to assess whether the implementation of content blocking systems like Cleanfeed is compliant with the CJEU case-law.

\section{The Legality of Content Blocking Systems from the CJeu Perspective}

Having exhausted the three-part Special Rapporteur's cumulative test that is whether under article 10(2) of the ECHR sections 17 and 18 of the DEA are "prescribed by law", in order to "protect the rights of others" ISPs, site operators and users' right to freedom of expression could be subject to blocking injunctions, and whether these restraining orders may

\footnotetext{
170 Informationsverein Lentia and others v Austria (App no 13914/88, App no15041/89, App no 15717/89, App no 15779/89, App no 17207/90) (1993) 17 EHRR 93[39].

${ }^{171}$ Twentieth Century Fox Film Corp \& Ors v British Telecommunications Plc [2011] EWHC 1981 (Ch) [200].

${ }^{172}$ Case 324/09 L'Oréal and Others [2011] ECR I-0000 [144].

173 Ofcom, "Site Blocking", to reduce online copyright infringement - A review of sections 17 and18 of the Digital Economy Act' < http://stakeholders.ofcom.org.uk/binaries/internet/site-blocking.pdf > at page 50, accessed 4 May, 2012.
} 
go further than what is reasonably "necessary"' and "proportionate"; for practical purposes, the last important consideration covered in this paper is to evaluate whether the implementation of content blocking systems respects the CJEU's case-law. As will be discussed, in Fox $v$ BT Arnold J regards the CJEU L'Oréal v eBay ${ }^{174}$ as authority for the proposition that under Article 15(1) of the E-Commerce Directive, the Cleanfeed filter does not require BT to perform active monitoring but merely to block Newzbin2. ${ }^{175}$ However, taking into account the main conclusions presented in Section I, Section II and Section III, regardless of Arnold J's finding this section will suggest how Fox $v B T$ could possibly be inconsistent with the CJEU's jurisprudence, once more with $S A B A M v$ Scarlet $^{176}$ and $S A B A M$ $v$ Netlog${ }^{177}$. Indeed this is particularly true when following Ofcom's review the UK government understands that the power to make provision about injunctions preventing access to internet locations appears to be an ineffective solution that fails to strike the right balance between the interests of content holders and those of ISPs, site operators and users. ${ }^{178}$

\section{A specific monitoring obligation}

To begin with, in Fox $v$ BT the High Court finds that the order sought by the studios does not constitute a general monitoring obligation but instead a limited and specific one. ${ }^{179}$ As Arnold J notes:

First, recital (47) of the E-Commerce Directive states that Article 15(1) does not "concern monitoring obligations in a specific case and, in particular, does not affect orders by national authorities in accordance with national legislation". ${ }^{180}$

Although not explicitly referred to in Fox $v B T$ it should be noted that following the CJEU in L'oreal v eBay the third sentence of Article 11 of Directive 2004/48/EC read together with Article 18 of Directive 2000/31/EC permit domestic courts to require an online service provider to adopt measures that not only result in terminating contraventions, but also in precluding further violations. ${ }^{181}$

\footnotetext{
${ }^{174}$ Case 324/09 L'Oréal and Others [2011] ECR I-0000.

175 Twentieth Century Fox Film Corp \& Ors v British Telecommunications Plc [2011] EWHC 1981 (Ch) [162].

${ }^{176}$ Case 70-10 Scarlet Extended SA v Société belge des auteurs, compositeurs et éditeurs SCRL (SABAM) [2012] ECDR 4

${ }^{177}$ Case 360-10 Belgische Vereniging van Auteurs, Componisten en Uitgevers CVBA (SABAM) v Netlog NV [2012] ECR I-0000

178 Ofcom, "Site Blocking"' to reduce online copyright infringement - A review of sections 17 and18 of the Digital Economy Act'< http://stakeholders.ofcom.org.uk/binaries/internet/site-blocking.pdf > at page 49, accessed 6 May, 2012.

${ }^{179}$ Twentieth Century Fox Film Corp \& Ors v British Telecommunications Plc [2011] EWHC 1981 (Ch) [161].

${ }^{180}$ Ibid [162].

${ }^{181}$ Case 324/09 L'Oréal and Others [2011] ECR I-0000 [127], [132].
} 
Secondly, in L'Oréal v eBay ${ }^{182}$ at [139] the CJEU regards "a general obligation to monitor" as "an active monitoring of all the data of each of [a website's] customers in order to prevent any future infringement". ${ }^{183}$ However, for practical purposes, the High Court's next finding becomes of paramount importance.

According to Arnold $\mathrm{J}$, in this case the injunction "does not require BT to engage in active monitoring of the kind described by the Court of Justice... but simply to block... the Newzbin2 website by automated means that do not involve detailed inspection of the data of any of BT's subscribers. ",184

Most interestingly, with regards to the level of monitoring, consistent with the Court the monitoring obligation "is specific rather than general. ",185

\section{Cleanfeed}

On the other hand, in Fox $v$ BT pursuant to Arnold $\mathrm{J}$ the order sought by the studios, also known as Cleanfeed is a hybrid filter of IP address blocking and Deep Packet Inspection (DPI)-based URL blocking which functions as a two-stage device. ${ }^{186}$

However, of particular relevance here is that the High Court observes that DPI can occur at three inspection levels; first, minimal analysis; second, summary analysis; or third, systematic, intrusive analysis. ${ }^{187}$

Yet, in considering whether content blocking systems respect the CJEU's case-law, another important point to note is that whilst according to Arnold J Cleanfeed "involves the first two levels of DPI analysis, but not the third" he is satisfied that "it is not necessary or appropriate to describe how it operates ', ${ }^{188}$

\footnotetext{
${ }^{182}$ Case 324/09 L'Oréal and Others [2011] ECR I-0000.

${ }^{183}$ Twentieth Century Fox Film Corp \& Ors v British Telecommunications Plc [2011] EWHC 1981 (Ch) [162].

${ }^{184}$ Ibid.

185 Ibid.

${ }^{186}$ Ibid [73].

${ }^{187}$ Ibid [72]

${ }^{188}$ Ibid [73].
} 
Notably, Arnold J's finding differs from Ofcom's review which explains that packet inspection blocking measures can be applied at two levels: "shallow packet inspection"' or more detailed level DPI. ${ }^{189}$

\section{How does Cleanfeed work?}

Although not being mentioned in Fox $v B T^{190}$ it is worth pointing out that following Dr Clayton's expert report Cleanfeed comprises a first stage filtering that resembles packet dropping. Notwithstanding, as Dr Clayton explains the major difficulty underlying packet dropping is the collateral damage that it produces because "all of the web content on the particular IP address will become inaccessible,' 191

Interestingly, according to Dr Clayton, Cleanfeed works as follows:

"the first stage examines all traffic flowing from customers along... path... a... If the traffic is innocuous, then it is sent along path $b$ to its destination in the normal way. If the traffic is for a suspect site, parts of which may be blocked, then it is redirected along path $c$ to the second stage filter. This first stage selection of traffic is based on the examination of the destination port number and IP address within the packets. The second stage filtering is implemented as a web proxy that understands HTTP requests. ",192

Crucially, in Golden Eye v Telefonica, Dr Clayton's expert evidence is convincing enough to be admitted and relied upon by Arnold J himself. ${ }^{193}$ Indeed, Dr Clayton's report is consistent with Ofcom's review which makes it clear that "shallow packet inspection" can be defined as blocking based on the port, IP address and protocol combination "e.g. all traffic destined for IP address 192.0.32.10, TCP on port 80 (web traffic) is dropped. ",194

\footnotetext{
189 Ofcom, "Site Blocking'" to reduce online copyright infringement - A review of sections 17 and18 of the Digital Economy Act' < http://stakeholders.ofcom.org.uk/binaries/internet/site-blocking.pdf > at page 39, accessed 15 October, 2012.

${ }^{190}$ Twentieth Century Fox Film Corp \& Ors v British Telecommunications Plc [2011] EWHC 1981 (Ch).

${ }^{191}$ Rychard Clayton, Anonymity and traceability in cyberspace (PhD thesis, University of Cambridge 2005$) 117$.

192 Ibid 120-21.

193 According to Arnold $\mathrm{J}$ in Golden Eye (International) Limited and others v Telefonica UK Limited [2012] EWHC 723 (Ch) [101], 'Consumer Focus served an expert report from Dr Richard Clayton. Dr Clayton is a Senior Research Assistant in the Computer Laboratory of the University of Cambridge. He worked for Demon Internet, then the largest UK ISP, from 1995 to 2000 . In 2006 he was awarded a PhD for his thesis "Anonymity and Traceability in Cyberspace". He has written or co-written some 40 peer-reviewed publications. He has advised Parliamentary Select Committees, and has acted as an expert witness in several criminal and civil cases'.

194 Ofcom, "Site Blocking", to reduce online copyright infringement - A review of sections 17 and18 of the Digital Economy Act' < http://stakeholders.ofcom.org.uk/binaries/internet/site-blocking.pdf > at page 39, accessed 15 October, 2012.
} 


\section{CopySense v Cleanfeed}

Moreover, it also has particular relevance to this section that in Fox $v$ BT the High Court finds that SABAM $v$ Scarlet $^{195}$ does not contain any technical information related to how CopySense functions. However, Arnold J concludes, that pursuant to EMI $v U P C^{196}$ his "understanding is that it involves DPI with detailed, invasive analysis of the contents of data packets, 197

Yet this is certainly interesting because in EMI $v U P C$ the Irish High Court explains that CopySense works as follows:

"It operates like an anti-virus programme in a sense that there is a database of signatures, in the case of CopySense signatures of copyright media... It does not monitor the contents of email, web travel, instant messaging, FDP, newsgroups, legal copyrights works being downloaded etc. ${ }^{, 198}$

Thus far, an important point to note here is that Ofcom's review clarifies that as opposed to DPI devices which analyse the contents of the packet for features or values it is possible employing "shallow packet inspection"' technology to gain access to other facilities, "such as e-mail or FTP, at the blocked site". 199

Taken together, as shown below, Charleton J's finding and Ofcom's review reveal that in SABAM v Scarlet ${ }^{200}$ and SABAM v Netlog ${ }^{201}$ the CJEU found the use of CopySense's "shallow packet inspection"' to be tantamount to a general monitoring obligation - which is precluded by Article 15(1) of Directive 2000/31/EC.

\footnotetext{
${ }^{195}$ Case 70-10 Scarlet Extended SA v Société belge des auteurs, compositeurs et éditeurs SCRL (SABAM) [2012] ECDR 4.

${ }^{196}$ EMI Records (Ireland) Ltd v UPC Communications Ireland Ltd [2010] IEHC 377.

${ }^{197}$ Twentieth Century Fox Film Corp \& Ors v British Telecommunications Plc [2011] EWHC 1981 (Ch) [167].

${ }^{198}$ EMI Records (Ireland) Ltd v UPC Communications Ireland Ltd [2010] IEHC 377 [44].

199 Ofcom, "Site Blocking" to reduce online copyright infringement - A review of sections 17 and 18 of the Digital Economy Act'< http://stakeholders.ofcom.org.uk/binaries/internet/site-blocking.pdf > at page 39, accessed 15 October, 2012.

${ }^{200}$ Case 70-10 Scarlet Extended SA v Société belge des auteurs, compositeurs et éditeurs SCRL (SABAM) [2012] ECDR 4.

${ }^{201}$ Case 360-10 Belgische Vereniging van Auteurs, Componisten en Uitgevers CVBA (SABAM) v Netlog NV [2012] ECR I-0000.
} 


\section{Unblocking the DEA from the CJEU perspective}

\section{Monitoring all electronic communications}

Firstly, in FOx $v$ BT Arnold $\mathrm{J}$ finds that the injunction sought by the studios "does not require" BT to perform "active monitoring'” as understood in L'Oréal v eBay 202 by the CJEU "but simply to block" Newzbin2. ${ }^{203}$ However, it could be reasonably contended that alternative conclusions might be drawn taking into account the same CJEU jurisprudence.

It is true that following the CJEU L'oreal v eBay the third sentence of Article 11 of Directive 2004/48/EC along with Article 18 of Directive 2000/31/EC permit domestic courts to require an online service provider to adopt measures that not only result in terminating contraventions, but also in precluding further violations. ${ }^{204}$

On the other hand, it has been shown earlier that according Dr Clayton's expert report, Cleanfeed's first stage filtering “examines all traffic flowing from customers". 205 Notwithstanding, the main difficulty underlying packet dropping is the collateral damage that it produces because "all of the web content on the particular IP address will become inaccessible,', 206

Or put differently, as the CJEU found in $S A B A M v$ Scarlet:

"In the present case, the injunction requiring the installation of the contested filtering system involves monitoring all the electronic communications made through the network of the ISP. ${ }^{, 207}$

Accordingly, in line with the CJEU, it must be concluded that the injunction can no longer be deemed to respect the fair balance between copyright protection, and the freedom for ISP's to conduct their business (Promusicae v Telefonica $\left.{ }^{208}\right){ }^{209}$

\footnotetext{
${ }^{202}$ Case 324/09 L'Oréal and Others [2011] ECR I-0000.

${ }^{203}$ Twentieth Century Fox Film Corp \& Ors v British Telecommunications Plc [2011] EWHC 1981 (Ch) [162].

${ }^{204}$ Case 324/09 L'Oréal and Others [2011] ECR I-0000 [127], [132].

${ }^{205}$ Rychard Clayton, Anonymity and traceability in cyberspace (PhD thesis, University of Cambridge 2005$) 120$.

206 Ibid 117.

${ }^{207}$ Case 70-10 Scarlet Extended SA v Société belge des auteurs, compositeurs et éditeurs SCRL (SABAM) [2012] ECDR 4 [47]; See also Case 360-10 Belgische Vereniging van Auteurs, Componisten en Uitgevers CVBA (SABAM) v Netlog NV [2012] ECR I-0000 [45].

${ }^{208}$ Case 275/06 Productores de Musica de Espana (Promusicae) v Telefonica de Espana SAU [2008] ECR I-271 [62-68].

${ }^{209}$ Case 70-10 Scarlet Extended SA v Société belge des auteurs, compositeurs et éditeurs SCRL (SABAM) [2012] ECDR 4 [45]; Case 360-10 Belgische Vereniging van Auteurs, Componisten en Uitgevers CVBA (SABAM) v Netlog NV [2012] ECR I-0000 [43].
} 
Thus, the first lesson that can be learnt from this paper is that for content blocking systems, such as, Cleanfeed to adequately strike the Promusicae balance one might debate that these filters should be devised to prevent the screening of "all" electronic communications.

\section{Infringing the fundamental rights of ISP's clients}

Secondly, in Fox $v$ BT Arnold $\mathbf{J}$ is satisfied that consistent with L'Oréal v eBay ${ }^{210}$ the injunction sought does "not involve detailed inspection of the data" of any of BT's clients. ${ }^{211}$ Nevertheless, again it is worth emphasising that pursuant to the CJEU in $S A B A M v$ Scarlet ${ }^{212}$ and $S A B A M v$ Netlog $^{213}$ the conclusion drawn here would be different.

As described above, Dr Clayton explains that Cleanfeed's first stage filtering is based on the inspection of the IP address and destination port number. On the other hand, the second stage is carried out as a web proxy that reads HTTP requests. ${ }^{214}$

Accordingly, as the CJEU correctly stresses, the impact of that injunction would not be restricted to the ISP involved, since the disputed blocking system might likewise violate the fundamental freedoms of that ISP's clients. ${ }^{215}$

Put another way:

"... first... the injunction... would involve a systematic analysis of all content and the collection and identification of users' IP addresses from which unlawful content on the network is sent. Those addresses are protected personal data... Secondly, that injunction could potentially undermine freedom of information since that system might not distinguish adequately between unlawful content and lawful content, with the result that its introduction could lead to the blocking of lawful communications. ",216

\footnotetext{
${ }^{210}$ Case 324/09 L'Oréal and Others [2011] ECR I-0000.

${ }^{211}$ Twentieth Century Fox Film Corp \& Ors v British Telecommunications Plc [2011] EWHC 1981 (Ch) [162].

${ }^{212}$ Case 70-10 Scarlet Extended SA v Société belge des auteurs, compositeurs et éditeurs SCRL (SABAM) [2012] ECDR 4.

${ }^{213}$ Case 360-10 Belgische Vereniging van Auteurs, Componisten en Uitgevers CVBA (SABAM) v Netlog NV [2012] ECR I-0000.

${ }^{214}$ Rychard Clayton, Anonymity and traceability in cyberspace (PhD thesis, University of Cambridge 2005) 121.

${ }^{215}$ Case 70-10 Scarlet Extended SA v Société belge des auteurs, compositeurs et éditeurs SCRL (SABAM) [2012] ECDR 4 [50]; Case 360-10 Belgische Vereniging van Auteurs, Componisten en Uitgevers CVBA (SABAM) v Netlog NV [2012] ECR I-0000 [48].

${ }^{216}$ Case 70-10 Scarlet Extended SA v Société belge des auteurs, compositeurs et éditeurs SCRL (SABAM) [2012] ECDR 4 [50], [51]; See also Case 360-10 Belgische Vereniging van Auteurs, Componisten en Uitgevers CVBA (SABAM) v Netlog NV [2012] ECR I-0000 [49], [50].
} 
Indeed, despite Arnold J's finding above in L'oreal v eBay the CJEU held that under Article 3 of Directive 2004/48/EC the court granting the injunction needs to guarantee that the measures “do not create barriers to legitimate trade.",217

Therefore, the second lesson that can be learnt from this paper is that for content blocking systems like Cleanfeed to conform to the CJEU's case-law they should also be designed taking into account the fundamental freedoms of the ISP's clients.

\section{Carrying out general monitoring}

Thirdly, in Fox $v$ BT the High Court finds that considering BT's level of monitoring, the monitoring obligation "is specific rather than general". ${ }^{218}$ Regrettably, the fact still remains, however, that another conclusion could be drawn from the same CJEU case-law.

There is no doubt that Article 18 of Directive 2000/31/EC compels Member States to ensure the quick implementation of measures intended not only to confront present but also future intellectual property infringement. ${ }^{219}$ Notwithstanding, in L'oreal v eBay the CJEU also adds that these conditions need to observe the exceptions emanating from Directive 2004/48. ${ }^{220}$

As discussed above, consistent with Dr Clayton, Cleanfeed's first stage analyses "all traffic" originating from clients. If the traffic is harmless, then it is directed to its destination. Nevertheless, if the traffic is from a suspicious website, elements of which might be filtered, then it is diverted to the second stage. ${ }^{221}$

Accordingly, following $S A B A M v$ Scarlet and $S A B A M v$ Netlog it is arguable that Cleanfeed would therefore be required to:

First, "identify", the files that are likely to include copyright protected works. Secondly, "determine"' which of these files are being kept and made publicly available illegally, and thirdly, "prevent', files deemed to be illegal from being made available. ${ }^{222}$

As the CJEU elaborates:

\footnotetext{
${ }^{217}$ Case 324/09 L'Oréal and Others [2011] ECR I-0000 [140].

${ }^{218}$ Twentieth Century Fox Film Corp \& Ors v British Telecommunications Plc [2011] EWHC 1981 (Ch) [162].

${ }^{219}$ Case 324/09 L'Oréal and Others [2011] ECR I-0000 [127], [144].

${ }^{220}$ Ibid [138].

${ }^{221}$ Rychard Clayton, Anonymity and traceability in cyberspace ( $\mathrm{PhD}$ thesis, University of Cambridge 2005) 120-21.

${ }^{222}$ Case 70-10 Scarlet Extended SA v Société belge des auteurs, compositeurs et éditeurs SCRL (SABAM) [2012] ECDR 4 [38]; Case 360-10 Belgische Vereniging van Auteurs, Componisten en Uitgevers CVBA (SABAM) v Netlog NV [2012] ECR I-0000 [36].
} 
"Preventive monitoring of this kind would thus require active observation of files... and would involve almost all of the information thus stored. ",223

Thus, "it follows that that injunction would require... to carry out general monitoring, something which is prohibited by Article 15(1) of Directive 2000/31., ,224

Resultantly, the third lesson that can be learnt from this paper is that for Cleanfeed's implementation not to result in general monitoring being performed again, these filters should arguably be created to evade "active observation" of content.

\section{Blocking measures inconsistency with article 15(1) of Directive 2000/31}

This section has analysed whether in light of the CJEU case-law the power to make provision about injunctions preventing access to internet locations strikes the right balance between the interests of copyright holders and those of ISPs, site operators and users. In Fox $v$ BT Arnold $\mathrm{J}$ finds that the order sought by the studios does not require BT to perform active monitoring but merely to block Newzbin2. ${ }^{225}$ However, as the CJEU in SABAMv Scarlet and SABAMv Netlog suggests, irrespective of how specifically monitoring is carried out, no shallow packet inspection device will ever be able to distinguish in an absolutely foolproof way between licensed and unlicensed content. ${ }^{226}$ Thus one of the most significant findings to emerge from this paper is that under Article 15(1) of Directive 2000/31/EC the implementation of content blocking systems like Cleanfeed is certainly likely to result in a prohibited act, namely, carrying out general monitoring. Consequently, another significant practical implication of this section is that in view of SABAMv Scarlet and SABAMv Netlog once more the UK could be in breach of European case-law. Therefore, no matter how sections 17 and 18 of the DEA are implemented, the main conclusion to be drawn from the above discussion is that pursuant to the CJEU's jurisprudence the blocking of legitimate speech would fail to strike the right balance between the interests of content owners and those of ISPs, site operators and users.

\footnotetext{
${ }^{223}$ Case 70-10 Scarlet Extended SA v Société belge des auteurs, compositeurs et éditeurs SCRL (SABAM) [2012] ECDR 4 [39]; Case 360-10 Belgische Vereniging van Auteurs, Componisten en Uitgevers CVBA (SABAM) v Netlog NV [2012] ECR I-0000 [37].

${ }^{224}$ Case 70-10 Scarlet Extended SA v Société belge des auteurs, compositeurs et éditeurs SCRL (SABAM) [2012] ECDR 4 [40]; Case 360-10 Belgische Vereniging van Auteurs, Componisten en Uitgevers CVBA (SABAM) v Netlog NV [2012] ECR I-0000 [38].

${ }^{225}$ Twentieth Century Fox Film Corp \& Ors v British Telecommunications Plc [2011] EWHC 1981 (Ch) [162].

${ }^{226}$ Case 70-10 Scarlet Extended SA v Société belge des auteurs, compositeurs et éditeurs SCRL (SABAM) [2012] ECDR 4 [52]; Case 360-10 Belgische Vereniging van Auteurs, Componisten en Uitgevers CVBA (SABAM) v Netlog NV [2012] ECR I-0000 [50].
} 


\section{OBSERVATIONS}

Leaving aside the original contribution that this paper adds to the creation of new knowledge regarding the compatibility of any blocking measure with article 10 of the ECHR, the major weakness inherent in this study concerns the method of data collection.

As discussed in the introduction, in February 2011, Jeremy Hunt asked Ofcom to assess whether sections 17 and 18 of the DEA could be effectively implemented. Notwithstanding, in May 2011, Ofcom concluded that the site blocking provisions would be ineffective. ${ }^{227}$

Therefore, following Ofcom's review this paper demonstrates why the UK's government's decision to abandon site-blocking plans appears appropriate. However, apart from judicial decisions, legislation, administrative law and independent expert evidence this study provides virtually no other relevant information to reach such a conclusion.

As Max Rowlands notes, Hunt's decision generated optimism among some detractors of the DEA. Nevertheless, in a matter of weeks The Guardian reported that the UK Minister for Cuture Ed Vaizey begun secret negotiations with content owners and ISPs to draft The Potential for a Voluntary Code ${ }^{228}$ - a proposal for a new website-blocking scheme. ${ }^{229}$

Rowlands argues that the UK government's decision to drop site-blocking plans does not reflect a changing attitude towards online censorship. Instead the established precedent under section 97A of the CDPA has provided them with the opportunity to drop sections 17 and 18 of the DEA without enraging the copyright industry which has exerted strong pressure for its introduction. ${ }^{230}$

However, whether the UK government's decision will eventually result in such contentious provisions being removed from the DEA remains to be seen. Indeed, this is particularly so when the Voluntary Code recognises that "a voluntary self-regulatory solution - if fully effective - could largely supplant the need for S17/18 DEA, which should nevertheless be implemented. ',231

\footnotetext{
${ }_{228}^{227}$ Ibid at page 50. $\quad$ Group, 'The Potential for a Voluntary Code' (June http://wiki.openrightsgroup.org/w/index.php?title=Voluntary_Website_Blocking_Proposal\&action=edit > accessed 1 June 2012.

${ }_{229}$ Max Rowlands, 'UK: Internet censorship looms as government finds alternatives to flawed Digital Economy Act' Statewatch (7 September 2011) < http://www.statewatch.org/analyses/no-147-internet-censorship.pdf > at page 6, accessed 1 June 2012. ${ }^{230} \mathrm{Ibid}$ at page 8 .

231 Rightsholder Group, 'The Potential for a Voluntary Code' (June 2011) http://wiki.openrightsgroup.org/w/index.php?title=Voluntary_Website_Blocking_Proposal\&action=edit $>$ accessed 1 June 2012.
} 
Thus far, after Next Steps for Implementation of the DEA $A^{232}$ in August 2011, the final step in the creation of the new voluntary scheme was in January 2012 when the UK government released Responsible Practices for Search Engines in Reducing Online Infringement Proposal for a Code of Practice. ${ }^{233}$

Accordingly, the introduction of yet another website-blocking code suggests that search engines should, inter alia:

- remove contravening links within a "maximum of 4 hours"; and

- ensure an "expedited process" which permits quick removal and blocking of contravening links. ${ }^{234}$

Or put differently, in the same way as in the Voluntary Code ${ }^{235}$ the above measures involve expedited blocking without judicial oversight or due process of any kind.

To do so, and what makes this even more worrying is that among other things search engines should carry out "active, ongoing, effective screening". ${ }^{236}$ In other words, under Article 15(1) of Directive 2000/31/EC the implementation of the new voluntary scheme could again result in a prohibited act, namely, imposing a general monitoring obligation upon search engines.

Consequently, although most of the findings presented in this paper are robust, the ones in support of the UK government's decision to abandon site-blocking plans are at best disputable, and at worst no longer sustainable.

\footnotetext{
232 Department for Culture, Media and Sport, 'Next steps for implementation of the Digital Economy Act' (August 2011) < http://www.culture.gov.uk/images/publications/Next-steps-for-implementation-of-the-Digital-Economy-Act.pdf > accessed 1 June 2012. ${ }^{233}$ Rightsholder Group, 'Responsible Practices for Search Engines in Reducing Online Infringement Proposal for a Code of Practice' (January 2012) < http://www.openrightsgroup.org/assets/files/pdfs/proposals\%20to\%20search\%20engines.pdf $>$ accessed 1 June 2012. ${ }^{234}$ Ibid.

235 Rightsholder Group, 'The Potential for a Voluntary Code' (June 2011) http://wiki.openrightsgroup.org/w/index.php?title=Voluntary Website Blocking Proposal\&action=edit $>$ accessed 1 June 2012.

${ }^{236}$ Rightsholder Group, 'Responsible Practices for Search Engines in Reducing Online Infringement Proposal for a Code of Practice' (January 2012) < http://www.openrightsgroup.org/assets/files/pdfs/proposals\%20to\%20search\%20engines.pdf $>$ accessed $1 \mathrm{June} 2012$.
} 